\title{
Ketahanan Kultivar Pisang Lokal Kalimantan Selatan terhadap Penyakit Bercak Sigatoka (Mycosphaerella sp.)
}

\author{
Resistance of South Kalimantan Local Banana Cultivars \\ Against Sigatoka Disease
}

\author{
Mariana*, Rodinah, Ismed Setya Budi \\ Universitas Lambung Mangkurat, Banjarbaru 70714
}

\begin{abstract}
ABSTRAK
Sigatoka yang disebabkan oleh Mycosphaerella sp. merupakan penyakit penting yang menyebabkan rendahnya kualitas dan kuantitas produksi pisang. Penanaman kultivar pisang yang tahan dianggap sebagai pendekatan yang menjanjikan untuk mengurangi kerugian akibat penyakit ini. Penelitian bertujuan menentukan ketahanan kultivar pisang lokal asal Kalimantan Selatan terhadap penyakit sigatoka. Cendawan diisolasi dari daun pisang kultivar Kapas dengan gejala sigatoka yang parah menggunakan medium agar-agar dekstrosa kentang. Isolat dikonfirmasi menggunakan postulat Koch. Isolat diidentifikasi sebagai Mycosphaerella $s p$. dan digunakan untuk menguji 11 kultivar pisang lokal yang tumbuh di Kalimantan Selatan. Tingkat ketahanan ditentukan berdasarkan perkembangan gejala. Kerapatan stomata masing-masing kultivar diukur. Secara umum gejala muncul 2 sampai 8 hari setelah inokulasi. Hasil penelitian menunjukkan terdapat perbedaan tingkat ketahanan, yaitu rentan ('Awak', 'Jaranang', 'Kapas', 'Mas', dan 'Paikat'), agak tahan ('Ambon', 'Kepok', 'Mas Bantan', 'Mauli', dan 'Talas'), dan tahan ('Tarati'). Masa inkubasi penyakit yang semakin panjang berhubungan dengan tingkat ketahanan yang tinggi. Intensitas penyakit berkorelasi negatif terhadap masa inkubasi, tetapi tidak berhubungan secara nyata dengan kerapatan stomata.
\end{abstract}

Kata kunci: intensitas penyakit, masa inkubasi, postulat Koch

\begin{abstract}
Sigatoka of banana caused by Mycospherella sp. is an important disease, since it causes yield losses. Resistant variety is considered a promising approach for sigatoka disease management. This study was aimed to evaluate the resistance of local banana cultivars from South Kalimantan against sigatoka disease. The fungus was isolated from leaves of Kapas cultivar showing severe symptoms of sigatoka disease, onto potato dextrose agar medium. The isolate was then confirmed as Mycosphaerella sp. following Koch's postulate. Level of resistance is determined based on symptoms development. Resistance of local banana cultivars can be differentiated into susceptible ('Awak', 'Jaranang', 'Kapas', 'Mas', and 'Paikat'), medium resistant ('Ambon', 'Kepok', 'Mas Bantan', 'Mauli', and 'Talas'), and resistant ('Tarati'). In general, the symptom was visible 2 to 8 days after inoculation. The longer incubation period the more resistant response of banana varieties. Incubation period was negatively correlated to the disease intensity, but it is not correlated with stomatal density.
\end{abstract}

Keyword: disease intensity, incubation period, Koch postulate

*Alamat penulis korespondensi: Jurusan Hama dan Penyakit Tumbuhan Fakultas Pertanian, Universitas Lambung Mangkurat. Jalan Jendral Ahmad Yani. KM 36, Banjarbaru 70714. Kotak Pos 1028.

Tel: 0511-4777392,Faks : 0511-4777392,Surel: mar_unlam@yahoo.com 


\section{PENDAHULUAN}

Cendawan Mycosphaerella musicola (anamorf: Pseudocercospora musicola) merupakan penyebab gejala Sigatoka Kuning sedangkan M. Fijiensis (Anamorf: Pseudocercospora fijiensis) penyebab gejala Sigatoka Hitam (Gomes et al. 2013). Penyakit ini dapat menyebabkan penurunan kecepatan fotosintesis dan transpirasi. Infeksi $M$. fijiensis juga menurunkan kandungan klorofil, sukrosa, pati, dan gula pada daun pisang yang mengakibatkan gangguan pertumbuhan dan produktivitas tanaman (RodriguezGaviria dan Cayon 2008). Penyakit sigatoka menyebabkan daun meranggas, buah yang berukuran kecil-kecil, menyebabkan bakal buah rontok, menurunkan kualitas buah, pematangan buah lebih awal, hingga produksi pisang menurun sampai 50\% (Ploetz 2007). Penyakit ini mematikan tanaman dengan lambat, tetapi jika tidak dikendalikan akan menimbulkan kerugian yang besar. Pada tahun 1995, di Costa Rica biaya untuk pengendalian penyakit sigatoka mencapai US\$900-1500 hasetiap tahunnya (Bennett dan Arneson 2003; Ploetz 2007). Taiwan Banana Research Institute mengendalikan penyakit sigatoka hitam dengan introduksi kultivar pisang yang tahan (ICDF 2013).

Terdapat beberapa jenis pisang yang banyak tumbuh subur dan banyak diusahakan di Kalimantan Selatan. Hal tersebut memberi peluang untuk mendapat pisang yang membawa gen tahan untuk merakit kultivar pisang yang lebih tahan penyakit sigatoka. Penelitian ini dilakukan untuk menguji tingkat ketahanan 11 kultivar pisang lokal Kalimantan Selatan terhadap penyakit sigatoka.

\section{BAHAN DAN METODE}

\section{Sumber Inokulum}

Sumber inokulum merupakan isolat patogen penyebab sigatoka yang telah di uji dengan postulat Koch. Dimulai dengan isolasi dari tanaman pisang kultivar Kapas yang bergejala bercak sigatoka hitam di Banjarbaru. Isolasi dilakukan dengan menumbuhkan cendawan pada medium agar-agar dekstrosa kentang (ADK) dan diinkubasi pada $\pm 26{ }^{\circ} \mathrm{C}$ selama 3-5 hari. Inokulasi potongan hifa miselium dilakukan pada daun pisang kultivar Kapas (kultivar rentan) dengan cara mengoleskan suspensi potongan (fragmen) miselium sebanyak $0.05 \mathrm{~mL}\left(12 \mathrm{mg} \mathrm{mL} \mathrm{mL}^{-1}\right.$ hifa dalam tween $200.05 \%$ ) pada permukaan bawah daun seluas $6 \times 6 \mathrm{~cm}^{2}$ menggunakan kuas halus (Donzelli dan Churchill 2007). Bagian ini ditutup dengan plastik transparan dan dijaga kelembapannya. Isolat cendawan yang menghasilkan gejala positif sigatoka pada daun pisang yang diinokulasi (Gambar 1b), dimurnikan, diidentifikasi dan disimpan sebagai biakan murni. Daun yang menunjukkan gejala penyakit sigatoka tersebut, diisolasi kembali dan dimurnikan serta diidentifikasi berdasarkan karakteristik morfologinya (Crous dan Mourichon 2002; Crous et al. 2007; Arzanlou et al. 2008; PaDIL 2011). Isolat dengan karakter morfologi makro dan mikro yang sama dengan isolat hasil isolasi awal, digunakan sebagai sumber inokulum. Isolat tersebut adalah isolate BS 1 .

\section{Uji Ketahanan Pisang}

Pisang uji yang digunakan berasal dari Banjarbaru, Kalimantan Selatan dan sekitarnya. Pisang terdiri atas 11 kultivar, yaitu pisang kultivar Awak, Ambon, Jaranang Habang, Kapas, Kepok, Mauli, Mas, Mas Bantan, Paikat, Talas, dan Tarati. Umur tanaman berkisar 3-4 bulan yang ditanam pada kantong plastik berukuran $19.5 \mathrm{~cm} \times 19.5$ $\mathrm{cm} \times 40 \mathrm{~cm}$ dengan medium campuran tanah dan sekam $(1: 1 \mathrm{v} / \mathrm{v})$. Setiap kultivar diulang 2 kali. Inokulasi patogen isolat BS 1 dilakukan seperti pada uji postulat Koch. Inokulasi dilakukan pada 5 bidang permukaan daun yang paling muda (sudah terbuka sempurna).

\section{Pengamatan}

Pengamatan dilakukan sejak gejala mulai terlihat. Peubah yang diamati ialah masa inkubasi patogen (hari inokulasi sampai timbulnya gejala pertama), intensitas penyakit, tingkat ketahanan varietas, dan kerapatan stomata tiap kultivar pisang. Intensitas 
penyakit diukur menggunakan rumus indeks infeksi modifikasi Gauhl (Carlier et al. 2002): Indeks infeksi $=\Sigma \frac{\mathrm{n} \times \mathrm{b}}{(\mathrm{N}-1) \times \mathrm{T}} \times 100 \%$, dengan

$\mathrm{n}$, jumlah daun dari tiap kategori serangan. $\mathrm{b}$, nilai skala tiap kategori serangan. $\mathrm{N}$,jumlah skor dalam skala ini (7). T, jumlah daun yang diskor.

Kategori skor yang digunakan untuk pengukuran intensitas penyakit sebagai berikut: Skor 0, tidak terserang; skor $1,<1 \%$ daun terserang; skor 2, 1-5\% daun terserang; skor 3, 5-15\% daun terserang; skor 4, 15$33 \%$ daun terserang; skor $5,33-50 \%$ daun terserang; dan skor $6,>50 \%$ daun terserang.

Tingkat ketahanan diklasifikasi berdasarkan pada tingkat perkembangan gejala sebagai berikut: tahan, tingkat perkembangan, gejala $0-1$; agak tahan, tingkat perkembangan gejala 2-3; dan rentan, tingkat perkembangan gejala 4-5 (Fullerton dan Olsen 1995).

Setiap tingkat perkembangan gejala dideskripsikan mengikuti Fullerton dan Olsen (1995), yaitu: tingkat 0, tidak terdapat gejala; tingkat 1, bercak berwarna kemerahan di bawah permukaan daun dan tidak terdapat gejala di atas permukaan daun; tingkat 2, bercak berwarna kemerahan, beraturan atau tidak beraturan pada bawah permukaan daun; tingkat 3 , bagian bercak terlihat pada permukaan daun bagian atas; tingkat 4 , bercak hitam atau cokelat, disertai halo kuning atau klorosis, kadang terdapat bagian bercak berwarna hijau; dan tingkat 5 , bercak hitam dengan bagian tengah berwarna abu-abu, daun mengalami nekrosis dan terkadang gugur.

\section{HASIL}

Hasil uji postulat Koch dan pengamatan morfologi patogen, menunjukkan cendawan penyebab bercak daun diidentifikasi dari genus Mycosphaerella, dengan anamorf Pseudocercospora. Pengamatan pada daun pisang kultivar Kapas dengan gejala sigatoka yang berasal dari lapang (Banjarbaru) (Gambar 1a), dan pada daun pisang hasil inokulasi (Gambar 1b), ditemukan struktur reproduksi patogen, saat 20 hari setelah inokulasi. Struktur reproduksi aseksual berupa sporodokium (konidioma) dan konidium (Gambar 1c). Konidium bervariasi dari soliter hingga bergerombol dalam sporodokium. Konidiumnnya tidak terlepas secara aktif, berwarna cokelat muda, lurus atau melengkung dengan ujung runcing, dan bersekat (3-7). Konidium juga ditemukan pada biakan di medium ADK (Gambar 1e). Struktur reproduksi seksual yang terdeteksi adalah askokarp (berupa peritesium) dan askospora (Gambar 1d). Berdasarkan karakter karakter tersebut, cendawan patogen diidentifikasi sebagai Mycosphaerella sp. (Crous dan Mourichon 2002; Arzanlou et al. 2008).

Pada pengamatan pertama intensitas penyakit tertinggi ialah pada pisang kultivar Mauli, yakni $20 \%$. Pada akhir pengamatan intensitas penyakit tertinggi ialah pada kultivar Kapas, Mauli, Mas, dan Jaranang berturutturut $71.67 \%, 56.67 \%, 51.67 \%$ dan $51.67 \%$ (Tabel 1). Pada kultivar Ambon, Awak, Mas Bantan, Talas, dan Tarati peningkatan

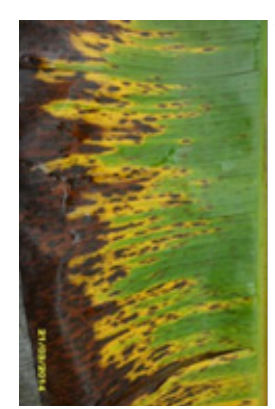

a

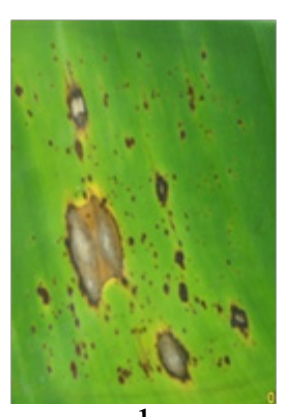

b

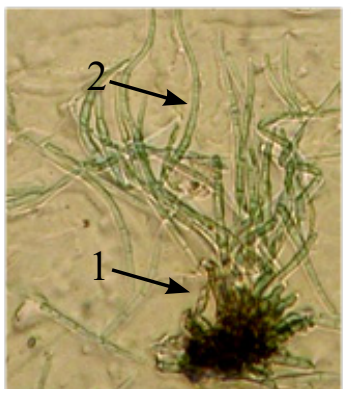

c

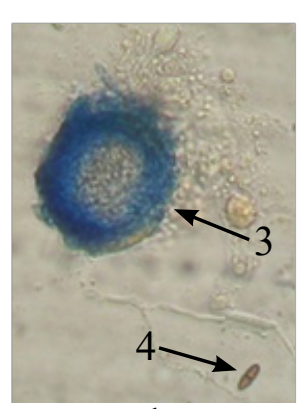

d

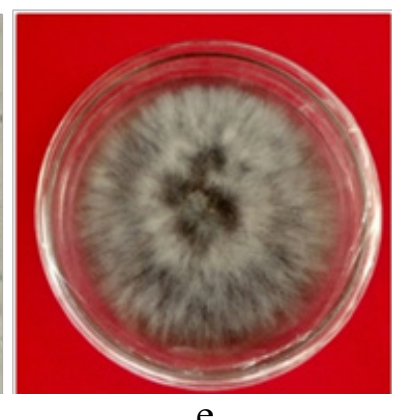

e

Gambar 1 Gejala penyakit sigatoka dan struktur morfologi Mycosphaerella sp. a, Gejala sigatoka di lapangan; b, Gejala hasil inokulasi; c, Struktur reproduksi aseksual Pseudocercospora; d, Struktur reproduksi seksual Mycosphaerella; dan e, Koloni cendawan. 1, Sporodokium; 2, Konidium; 3, Askokarp; 4, Askospora. 
intensitas tertinggi terjadi pada pengamatan ke-4 dan di pengamatan ke-2 untuk kultivar lainnya. Namun, perkembangannya melambat pada pengamatan selanjutnya (Gambar 2).

Masa inkubasi terpanjang dijumpai pada pisang kultivar Tarati, yaitu 8 hari setelah inokulasi yang dikategorikan sebagai kultivar tahan. Pisang kultivar lain masa inkubasinya lebih singkat sehingga tingkat ketahanannya dikategorikan lebih rendah (Tabel 1). Korelasi antara masa inkubasi dengan intensitas penyakit di akhir pengamatan menunjukkan nilai negatif, artinya semakin panjang masa inkubasi maka intensitas serangan akan semakin rendah (Gambar 3). Hubungan kedua faktor tersebut kuat, yakni 52.61\% $(\mathrm{R}=-0.52611)$. Namun, faktor masa inkubasi hanya mampu menjelaskan faktor intensitas serangan sebesar $27.68 \%(\mathrm{R} 2=0.2768)$.

Kerapatan stomata dan intensitas penyakit berkorelasi negatif artinya intensitas serangan semakin rendah apabila kerapatan stomata meningkat. Jika dilihat dari nilai $\mathrm{R}$ yang kurang dari $0.5(\mathrm{R}=-0.23664)$ maka hubungan kedua faktor tersebut dikategorikan lemah. Kerapatan stomata hanya mampu menjelaskan

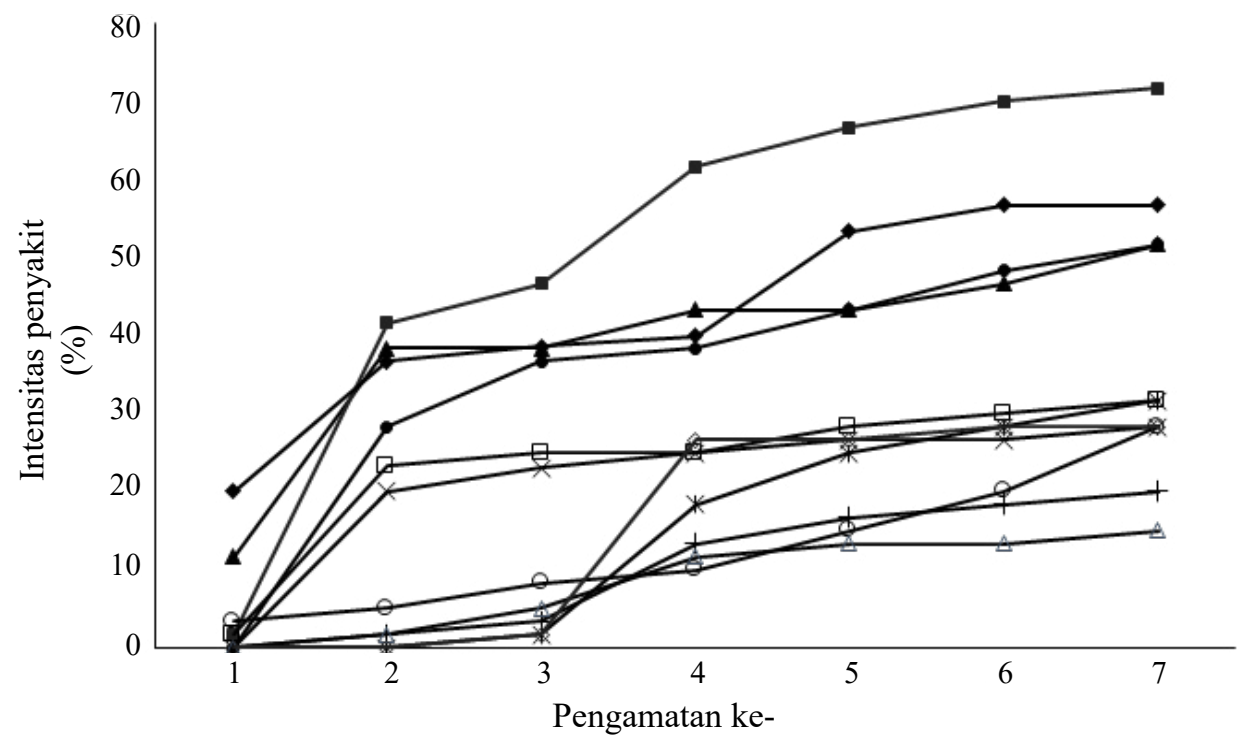

Gambar 2 Perkembangan intensitas penyakit sigatoka pada 11 kultivar pisang lokal Kalimantan Selatan yang diinokulasikan dengan suspensi hifa. Pengamatan ke-1 ialah hari mulai munculnya gejala pada masing masing kultivar, pengamatan selanjutnya interval 3 hari. Jenis kultivar pisang: $\rightarrow$, Ambon; $\rightarrow$, Awak; $\rightarrow$, Jaranang; $\rightarrow$, Kapas; $\rightarrow$, Kepok; $\rightarrow$, Mas; $\rightarrow$, Mas Batan; $\rightarrow$, Mauli; $\longrightarrow$, Paikat; $\longrightarrow$, Talas; $\longrightarrow$, Tarati.

Tabel 1 Masa Inkubasi, Intensitas Penyakit, Kerapatan Stomata dan Tingkat Ketahanan beberapa kultivar pisang di Kalimantan Selatan

\begin{tabular}{lcccc}
\hline Kultivar pisang & $\begin{array}{c}\text { Masa inkubasi } \\
(\text { hari })\end{array}$ & $\begin{array}{c}\text { Intentas penyakit } \\
(\%)\end{array}$ & $\begin{array}{c}\text { Kerapatan stomata } \\
\left(\text { stomata } \mathrm{mm}^{-2}\right)\end{array}$ & $\begin{array}{c}\text { Tingkat } \\
\text { ketahanan }\end{array}$ \\
\hline Ambon & 5 & 20.00 & 139 & Agak tahan \\
Awak & 7 & 31.67 & 158 & Rentan \\
Jaranang Habang & 2 & 51.67 & 111 & Rentan \\
Kapas & 3 & 71.67 & 111 & Rentan \\
Kepok & 5 & 28.33 & 178 & Agak tahan \\
Mauli & 2 & 56.67 & 127 & Agak tahan \\
Mas & 4 & 51.67 & 175 & Rentan \\
Mas bantan & 4 & 28.33 & 94 & Agak tahan \\
Paikat & 2 & 31.67 & 151 & Rentan \\
Talas & 5 & 15.00 & 139 & Agak tahan \\
Tarati & 8 & 28.33 & 138 & Tahan \\
\hline
\end{tabular}


faktor intensitas serangan sebesar $5.60 \%$ $(\mathrm{R} 2=0.056)$ (Gambar 4).

\section{PEMBAHASAN}

Lama masa inkubasi pada penelitian ini lebih singkat sekitar 2-8 hari dibandingkan dengan hasil penelitian Taylor (2005) yang melaporkan sekitar 8-10 hari setelah inokulasi. Donzelli dan Churchill (2007) melaporkan masa inkubasi $M$. fijiensis di lapangan berkisar 10-14 hari setelah inokulasi dan 35 hari pada iklim kering, serta berkisar 12-21 hari apabila diletakkan di rumah kaca. Lama masa inkubasi dipengaruhi oleh tingkat ketahanan tanaman inang dan virulensi patogen. Adanya korelasi yang kuat antara masa inkubasi dan intensitas penyakit menunjukkan bahwa masa inkubasi merupakan komponen dari ketahanan tanaman terhadap penyakit sigatoka (Leiva-Mora et al. 2015). Masainkubasimemilikiketerkaitanyang erat dengan tingkat ketahanan. Apabila tingkat ketahanan semakin tinggi maka masa inkubasi akan semakin panjang, begitu juga sebaliknya.

Kerapatan stomata merupakan faktor yang memengaruhi ketahanan tanaman terutama untuk patogen yang penetrasinya melalui stomata. M. musicola masuk melalui stomata yang terbuka (Kannan dan Prakasam 2012). Lemahnya korelasi antara kerapatan stomata

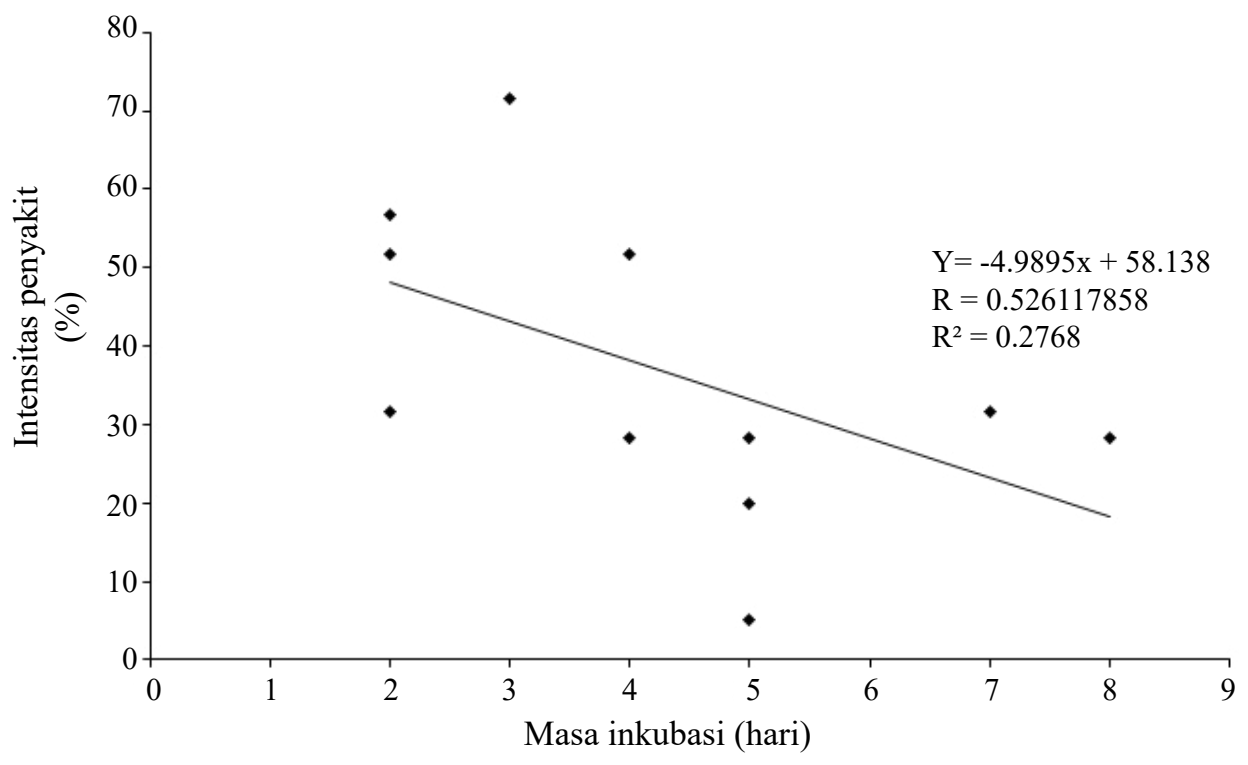

Gambar 3 Hubungan masa inkubasi dengan intensitas penyakit bercak sigatoka.

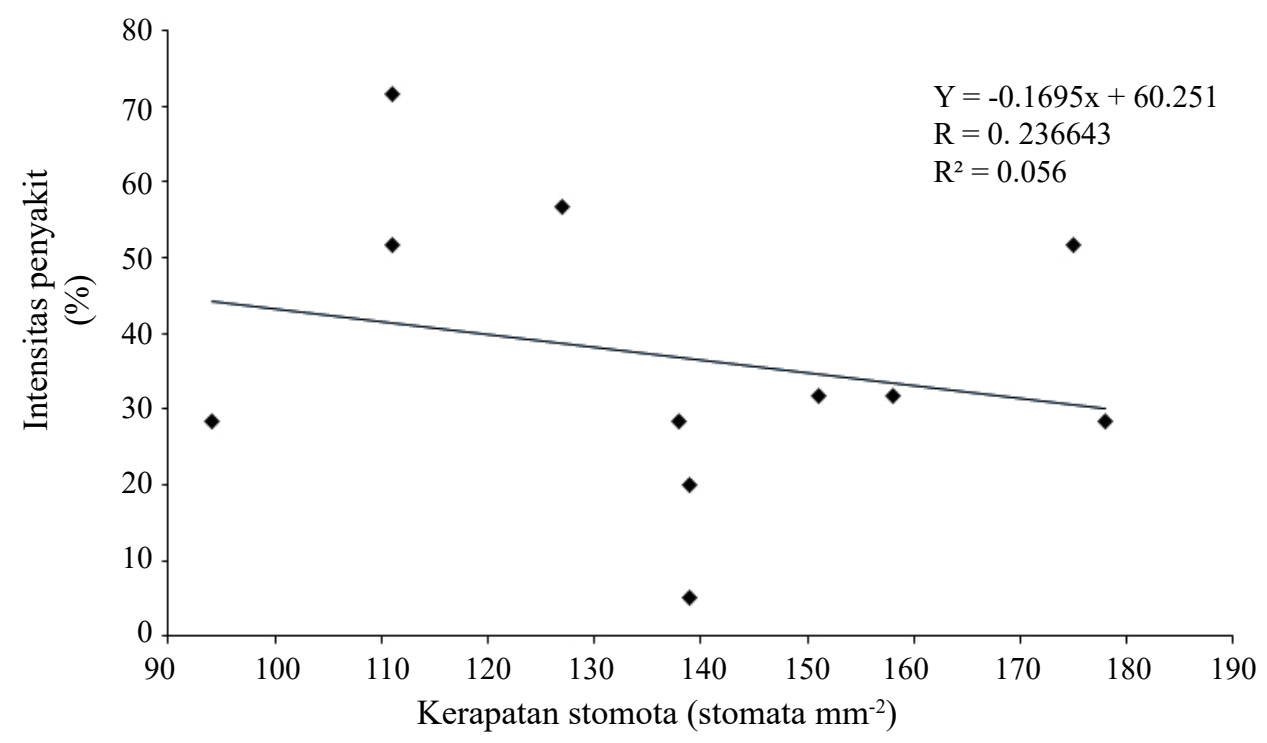

Gambar 4 Hubungan kerapatan stomata dengan intensitas penyakit bercak sigatoka. 
dan intensitas penyakit pada penelitian ini menunjukkan ada faktor ketahanan lain yang berperan lebih dominan. Faktor fisik lainnya yang berperan terhadap ketahanan ialah ketebalan dinding sel epidermis. Kultivar pisang tahan memiliki kutikula yang lebih tebal daripada yang rentan (Aliah et al 2015).

Pada kultivar pisang tahan seperti Tarati memiliki gen tahan, yaitu gen bsr (Black Sigatoka Resistant) (Orluchukwu dan Ogburia, 2014) yang menyebabkan reaksi hipersensitif segera terjadi setelah infeksi sehingga mampu membatasi aktivitas patogen (Sánchez et al. 2016). Hal ini juga berkaitan dengan toksin yang dihasilkan oleh $M$. fijiensis yang terlibat dalam inisiasi infeksi, maupun dalam reaksi hipersensitif. Pada kultivar agak tahan seperti Kepok, Mauli, Mas Bantan dan Talas, toksin ini berkontribusi terhadap perluasan lesio (nekrosis) (Harelimana et al. 1997). Toksin (5-hydroxy-1,4-naphthoquinone) dari $M$. fijiensis berperan penting dalam perkembangan gejala bercak daun karena menghambat fungsi kloroplas dalam transfer elektron (Busogoro et al. 2004); fitotoksin bersifat tidak spesifik inang (Cruz-Cruz et al. 2011). Lepoivre et al. (2003) menjelaskan pada interaksi tanaman pisang dengan $M$. fijiensis yang tidak kompatibel (reaksi tahan) karena kematian sel penjaga stomata terjadi diawal, dan terjadi penumpukan senyawa dengan elektron yang padat mengelilingi tempat infeksi. Kurangnya peran kerapatan stomata terhadap intensitas penyakit disebabkan karena tabung kecambah cendawan Mycosphaerella sp. bisa menyeberangi stomata tanpa melakukan penetrasi (Kema et al. 1996).

Gen ketahanan terhadap penyakit bercak sigatoka bersifat resesif, sedangkan gen rentan bersifat dominan (Etebu dan Young-Harry 2011). Oleh karena itu, meskipun pada tanaman rentan terdapat gen tahan, tetapi ekspresi gen ini tertutupi oleh gen rentan sehingga tanaman menjadi rentan. Hal tersebut menyebabkan kultivar yang dikategorikan rentan dalam penelitian ini lebih banyak dibandingkan dengan kultivar tahan.

\section{DAFTAR PUSTAKA}

Aliah NU, Sulistyowati L, Muhibbudin A. 2015. Hubungan ketebalan lapisan epidermis daun terhadap serangan jamur (Mycosphaerella musicola) penyebab penyakit bercak daun sigatoka pada sepuluh kultivar pisang. JHPT Tropika. 3(1):35-43.

Arzanlou M, Groenewald JZ, Fullerton RA, Abeln ECA, Carlier J, Zapater M-F, Buddenhagen IW, Viljoen A, Crous PW. 2008. Multiple gene genealogies and phenotypic characters differentiate several novel species of Mycosphaerella and related anamorphs on Banana. Persoonia. 20:19-37. DOI: https://doi. org/10.3767/003158508X302212.

Busogoro JP, Etamé JJ, Lognay G, Messiaen J, van Cutsem P, Lepoivre P. 2004. Analysis of the mechanisms of action of Mycosphaerella fijiensis toxins during the development of black leaf streak disease. http://www.fao.org/docrep/007/ae216e/ ae216e0g.htm (diakses 28 Juni 2016).

Bennett RS, Arneson PA. 2003. Black Sigatoka of bananas and plantains. http:// www.apsnet.org/edcenter/intropp/lessons/ fungi/ascomycetes/Pages/BlackSigatoka. aspx (diakses 12 Juli 2015). DOI: https:// doi.org/10.1094/PHI-I-2003-0905-01.

Carlier J, De Waele D, Escalant JV. 2002. Global evaluation of Musa germplasm for resistance to Fusarium wilt, Mycosphaerella leaf spot diseases and nematodes: In-dept Evaluation Vol. 6. Montpellier:(FR).Biodiversity International. hlm 45-46

Crous PW, Braun U, Groenewald JZ. 2007. Mycosphaerella is polyphyletic. Studies in Mycology. 58:1-32. DOI: https://doi. org/10.3114/sim.2007.58.01.

Crous PW, Mourichon X. 2002. Mycosphaerella eumusae and its anamorph Pseudocercospora eumusae spp nov: causal agent of eumusae leaf spot disease of banana. Sydowia. 54(1):35-43.

Cruz-Cruz CA, Garcia-Sosa K, EscalanteErosa F, Pena-Rodriguez LM. 2011. 
Physiological effects of the hydrophilic phytotoxins produced by Mycosphaerella fijiensis, the causal agent of black sigatokain banana plants. J Gen Plant Pathol. 77:93100. DOI: https://doi.org/10.1007/s10327010-0288-4.

Donzelli BGG, Churchill ACL. 2007. A quantitative assay using mycelial fragments to assess virulence of Mycosphaerella fijiensis. Phytopathology. 97(8):916929. DOI: https://doi.org/10.1094/ PHYTO-97-8-0916.

Etebu E, Young-Harry W. 2011. Control of black sigatoka disease: challenges and prospects. Afr J Agric Res. 6(3):508-514.

Fullerton RA, Olsen TL. 1995. Pathogenic variability in Mycosphaerella fijiensis Morelet, cause of black sigatoka in banana and plantain. J Crop Hort Sci. 23:39-48. DOI: https://doi.org/10.1080/01140671.19 95.9513866.

Gomes LIS, Douhan GW, Bibiano LBJ, Maffia LA, Mizubuti ESG. 2013. Mycosphaerella musicola identified as the only pathogen of the sigatoka disease complex present in Minas Gerais State, Brazil. Plant Disease. 97(12):1537-1543. DOI: https://doi. org/10.1094/PDIS-12-12-1212-RE.

Harelimana G, Lepoivre P, Jijakli H, Mourichon X. 1997. Use of Mycosphaerella fijiensis toxins for the selection of banana cultivars resistant to black leaf streak. Euphytica. 96(1):125-128. DOI: https:// doi.org/10.1023/A:1002960902950.

ICDF (International Cooperationand Development Fund). 2013. Banana Black Sigatoka Disease Prevention and Treatment Project (St. Lucia) http://www. icdf.org.tw/ct.asp?xItem $=18907 \&$ CtNo $\mathrm{de}=29823 \& \mathrm{mp}=2$ (diakses 23 November 2015.

Kannan C, Prakasam V. 2012. Ultra structural studies on the infection process of Mycosphaerella musicola-causal agent of yellow sigatoka on banana. Indian Phytopath. 65(2):192-195.

Kema GHJ, Yu D, Rijkenberg FHJ, Shaw MW and Baayen RP. 1996. Histology of pathogenesis of Mycosphaerella graminicola in wheat. Phytopathology 86(7):777-786. DOI: https://doi. org/10.1094/Phyto-86-777.

Leiva-Mora M, Capó YA, Suárez MA, Martín MC, Roque B, Méndez EM. 2015. Components of resistance to assess black sigatoka response in artificially inoculated Musa genotypes. Revista de Protección Vegetal. 30(1):60-69.

Lepoivre P, Busogoro JP, Etame JJ, El Hadrami A, Carlier J, Harelimana G, Mourichon X, Panis B, Stella RA, Sallé G, Strosse H, Swennen R. 2003. Banana Mycosphaerella fijiensis Interactions. Di dalam: Proceedings of the 2nd International workshop on Mycosphaerella leaf spot diseases International Network for the Improvement of Banana and Plantain, 20-23 May 2002. MontpellierFranch. International Network for the Improvement of Banana and Plantain (INIBAP). hlm 151-159

Orluchukwu JA, Ogburia MN. 2014. Introgression of bsr gene from wild $2 \mathrm{n}$ accessions and derivative hybrids to cultivated $3 \mathrm{n}$ landraces of plantains (Musa sp.). Inter J Plant Res. 4(1):1-4.

PaDIL (Pest and Disease Image Library). 2009. Diagnostic Methods for Black Sigatoka Mycosphaerella fijiensis. http:// www.padil.gov.au/pbt (diakses 13 januari 2015).

Ploetz RC. 2007. Diseases of tropical perennial crops: challenging problems in diverse environments. Plant Dis. 91(6):644-663. https://doi.org/10.1094/PDIS-91-6-0644.

Rodriguez-Gaviria PA, Cayon G. 2008. Physiological effect of Mycosphaerella fijiensis in banana leaves. Agron Colomb. 26(2):256-265.

Sánchez TE, Hidalgo PL, Pacheco CR, Chávez NT, NavarreteVO, Santos OE. 2016. Identification of differentially-expressed genes in response to Mycosphaerella fijiensis in the resistant musa accession 'Calcutta-4' using suppression subtractive hybridization. PLoS ONE. 11(8):1-17. DOI: https://doi.org/10.1371/journal. pone. 0160083 . 
Taylor MK. 2005. Characterization of potential fungal disease resistance genes in banana [tesis]. Quensland University of Technology. 